J. Dairy Sci. 95:3997-4005

http://dx.doi.org/10.3168/jds.2011-5174

(C) American Dairy Science Association ${ }^{\circledR}, 2012$.

\title{
Nationwide evaluation of quality and composition of colostrum on dairy farms in the United States
}

\author{
K. M. Morrill, ${ }^{* 1}$ E. Conrad, $†$ A. Lago,$\ddagger^{2}$ J. Campbell, $\neq$ J. Quigley, $\nmid \ddagger^{3}$ and H. Tyler $†$ \\ ${ }^{*}$ Cornell Cooperative Extension, Cornell University, Ithaca 14853 \\ †Department of Animal Science, lowa State University, Ames 50014 \\ ‡APC Inc., Ankeny, IA 50021
}

\section{ABSTRACT}

The objective of this study was to characterize the quality of maternal colostrum (MC) fed to newborn dairy calves in the United States and identify the proportion of MC that meets industry standards for IgG concentration and total plate count (TPC). Samples of MC $(\mathrm{n}=827)$ were collected from 67 farms in 12 states between June and October 2010. Samples were collected from Holsteins $(\mathrm{n}=494)$, Jerseys $(\mathrm{n}=87)$, crossbred $(\mathrm{n}=7)$, and unidentified dairy cattle $(\mathrm{n}=$ 239) from first $(\mathrm{n}=49)$, second $(\mathrm{n}=174)$, third or greater $(\mathrm{n}=128)$, and unknown $(\mathrm{n}=476)$ lactations. Samples were identified as fresh $(\mathrm{n}=196)$, refrigerated $(\mathrm{n}=152)$, or frozen $(\mathrm{n}=479)$ before collection, as well as whether the sample was from an individual cow (n $=734)$ or pooled $(\mathrm{n}=93)$. Concentration of $\operatorname{IgG}$ in $\mathrm{MC}$ ranged from $<1$ to $200 \mathrm{mg} / \mathrm{mL}$, with a mean $\mathrm{IgG}$ concentration of $68.8 \mathrm{mg} / \mathrm{mL}(\mathrm{SD}=32.8)$. Almost $30 \%$ of $\mathrm{MC}$ contained $<50 \mathrm{mg}$ of $\mathrm{IgG} / \mathrm{mL}$. The IgG concentration increased with parity $(42.4,68.6$, and 95.9 $\mathrm{mg} / \mathrm{mL}$ in first, second, and third and later lactations, respectively). No differences in IgG concentration were observed among breeds or storage method; however, IgG was highest in samples collected in the Midwest and lowest in samples collected in the Southwest (79.7 vs. $64.3 \mathrm{mg} / \mathrm{mL}$ ). Total plate count of samples ranged from 3.0 to $6.8 \log _{10} \mathrm{cfu} / \mathrm{mL}$, with a mean of $4.9 \log _{10}$ $\mathrm{cfu} / \mathrm{mL}(\mathrm{SD}=0.9)$ and was greater in samples collected in the Southeast compared with other regions of the country. Pooled samples had greater TPC than individual samples and refrigerated samples had greater TPC than frozen and fresh samples. Almost $43 \%$ of samples collected had TPC $>100,000 \mathrm{cfu} / \mathrm{mL}, 16.9 \%$ of the samples had $>1$ million $\mathrm{cfu} / \mathrm{mL}$. Only $39.4 \%$ of

Received November 22, 2011.

Accepted March 13, 2012.

${ }^{1}$ Corresponding author: kmm434@cornell.edu

${ }^{2}$ Current address: Dairy Experts, Tulare, CA 93274

${ }^{3}$ Current address: Provimi North America, Brookville, OH 45309. the samples collected met industry recommendations for both IgG concentration and TPC. Almost $60 \%$ of $\mathrm{MC}$ on dairy farms is inadequate, and a large number of calves are at risk of failure of passive transfer or bacterial infections, or both. Also, these data indicate that regional differences exist in colostrum quality.

Key words: colostrum, total plate count, immunoglobulin G, coliform

\section{INTRODUCTION}

Maternal colostrum (MC) provides the neonate with IgG essential for passive immunity. Carbohydrates, fat, and protein in MC are also essential as metabolic fuels to the newborn (NRC, 2001). Vitamins and minerals in $\mathrm{MC}$ are essential as cofactors for enzymes and general maintenance functions.

The newborn calf is born with relatively few energy reserves, with lipids comprising only $3 \%$ of BW. Much of this lipid content is structural and does not contribute to energy needs of the calf. Newborn calves rely on lipids and lactose in $\mathrm{MC}$ and milk as energy sources for thermogenesis and maintenance of body temperature. The energy content of $\mathrm{MC}$ can vary greatly.

Non-IgG proteins in MC provide nutrition; enhancement of the immune system; act as a defense against pathogenic bacteria, viruses and yeast; and are important for the development of the gastrointestinal tract (Bösze et al., 2008). The biological properties of proteins in MC work to facilitate nutrient assimilation, whereas peptides potentially influence the growth and differentiation of various neonatal tissues (Talukder et al., 2002). Large quantities of AA are also needed for the rapid protein accretion that occurs independent of $\operatorname{IgG}$ accumulation in the digestive tract (Davis and Drackley, 1998).

Colostral IgG concentration is essential to ensuring adequate passive transfer (Nocek et al., 1984); however, bacterial contamination of $\mathrm{MC}$ is another critical quality parameter. Bacteria in MC may bind free IgG in the gut lumen or block uptake and transport of $\operatorname{IgG}$ molecules into the enterocytes (James and Polan, 1978; 
James et al., 1981), thus reducing apparent efficiency of IgG absorption (Johnson et al., 2007). Current industry recommendations include discarding $\mathrm{MC}$ that contains $<50 \mathrm{mg}$ of $\mathrm{IgG} / \mathrm{mL}$ and $>100,000 \mathrm{cfu} / \mathrm{mL}$ total plate count (TPC; McGuirk and Collins, 2004). Previous survey data has focused on colostrum management practices: volume of $\mathrm{MC}$ fed, timing of first feeding, if $\mathrm{MC}$ is tested and how, or how the MC was stored before feeding (NAHMS, 2007a; Fulwider et al., 2008). Kehoe et al. (2007) reported both management practices and nutrient composition of MC collected from 55 Pennsylvania dairy farms. Only $1 \mathrm{MC}$ sample from each farm was collected within $4 \mathrm{~h}$ of parturition for analysis; bacterial counts as well as lactation and breed breakdowns were not reported. Their study concluded that although improvements had been made in colostrum management practices, there was room for further improvement.

A major limitation to previous colostrum composition studies is that MC samples have been collected immediately following milking and may not necessarily represent MC that is eventually fed to the newborn. Following collection, potential exists for additional bacterial contamination (Stewart et al., 2005; Godden, 2008).

Few data are available regarding the percentage of MC fed in the United States that meets both quality recommendations and whether regional differences exist in colostrum composition. The objectives of this study were to 1) determine the IgG concentration, nutrient, and bacterial composition of MC available on US dairy farms, 2) determine nutrient and bacterial differences in MC across regions, storage methods, breeds, and parity, and 3) estimate the percentage of MC available that meets industry standards for both IgG concentration and bacterial contamination.

\section{MATERIALS AND METHODS}

\section{Farm Selection}

Dairy farms $(\mathrm{n}=67)$ in 12 states participated in the study between June and October 2010 (Table 1). Participating farms were required to feed supplemented and unpasteurized MC. Farms were also required to complete 2 management surveys. Farms ranged from 70 to over 5,000 lactating dairy cows. States were grouped into 4 regions: Northeast (New Hampshire, New York, and Pennsylvania), Southeast (Florida, Georgia, and Virginia), Midwest (Iowa, Minnesota, and Wisconsin), or Southwest (Arizona, California, and Texas).

\section{Colostrum Sample Collection}

The number of MC samples collected from each dairy was based on availability of MC at the time of site visit. Frozen, refrigerated, or fresh MC was selected. The MC was sampled from individual cows or from multiple cow pools according to the normal management of the farm. A 50-mL sample of MC was collected using a sterile dipper and divided into 2 sample vials (45 and $3 \mathrm{~mL}$ ), frozen $\left(-20^{\circ} \mathrm{C}\right)$, placed on dry ice, and shipped to the

Table 1. Colostrum samples collected across region, state, breed, lactation, and storage method

\begin{tabular}{|c|c|c|c|c|c|c|c|c|c|c|c|c|c|c|}
\hline \multirow{2}{*}{$\begin{array}{l}\text { Region } \\
\text { and state }\end{array}$} & \multirow{2}{*}{$\begin{array}{l}\text { No. of } \\
\text { farms }\end{array}$} & \multirow{2}{*}{$\begin{array}{c}\text { No. of } \\
\text { samples }\end{array}$} & \multicolumn{4}{|c|}{ Breed (n) } & \multicolumn{5}{|c|}{ Lactation } & \multicolumn{3}{|c|}{ Storage $^{2}$} \\
\hline & & & Holstein & Jersey & Crossbred & $\mathrm{N} / \mathrm{A}^{3}$ & 1 & 2 & 3 & $4+$ & $\mathrm{N} / \mathrm{A}^{3}$ & 1 & 2 & 3 \\
\hline \multicolumn{15}{|l|}{ Northeast } \\
\hline $\mathrm{NH}$ & 1 & 18 & 18 & - & - & - & - & 6 & 3 & 9 & - & 18 & - & - \\
\hline NY & 5 & 59 & 41 & 3 & - & 15 & 4 & 11 & 4 & 2 & 38 & 17 & 29 & 13 \\
\hline $\mathrm{PA}$ & 5 & 51 & 42 & 9 & - & - & - & 5 & 17 & 22 & 7 & - & 23 & 28 \\
\hline \multicolumn{15}{|l|}{ Southeast } \\
\hline FL & 4 & 35 & 33 & 2 & - & - & 1 & 22 & - & - & 12 & 17 & 9 & 9 \\
\hline GA & 2 & 30 & 30 & - & - & - & - & 30 & - & - & - & 11 & 19 & - \\
\hline VA & 7 & 60 & 22 & 3 & & 35 & - & 2 & 1 & - & 57 & 25 & 20 & 15 \\
\hline \multicolumn{15}{|l|}{ Midwest } \\
\hline IA & 1 & 40 & 40 & - & - & - & - & & - & - & 40 & - & - & 40 \\
\hline $\mathrm{MN}$ & 11 & 97 & 35 & - & - & 62 & 8 & 10 & 4 & 5 & 70 & 2 & 6 & 89 \\
\hline WI & 6 & 27 & 27 & - & - & - & - & 5 & - & - & 22 & - & - & 27 \\
\hline \multicolumn{15}{|l|}{ Southwest } \\
\hline AZ & 2 & 61 & 40 & - & - & 21 & 2 & 7 & - & - & 52 & 7 & 9 & 45 \\
\hline $\mathrm{CA}$ & 14 & 173 & 161 & 8 & - & 4 & 34 & 76 & - & - & 63 & 93 & 34 & 46 \\
\hline $\mathrm{TX}$ & 9 & 176 & 5 & 62 & 7 & 102 & - & & 61 & - & 115 & 6 & 3 & 167 \\
\hline Total & 67 & 827 & 494 & 87 & 7 & 239 & 49 & 174 & 90 & 38 & 476 & 196 & 152 & 479 \\
\hline
\end{tabular}

${ }^{1}$ Region and state in the United States. $\mathrm{NH}=$ New Hampshire; NY = New York; PA = Pennsylvania; FL = Florida; GA = Georgia; VA = Virginia; IA = Iowa; $\mathrm{MN}=$ Minnesota; WI = Wisconsin; $\mathrm{AZ}=$ Arizona; CA = California; $\mathrm{TX}=\mathrm{Texas}$.

${ }^{2}$ Location where colostrum was stored before sampling: $1=$ fresh $/$ not stored; $2=$ refrigerator; $3=$ freezer.

${ }^{3}$ Unidentified. 
Table 2. Overall sample means for IgG, nutrients, and bacterial contamination

\begin{tabular}{lcrrrr}
\hline Item & $\mathrm{n}$ & Mean & $\mathrm{SD}$ & Minimum & Maximum \\
\hline IgG (mg/mL) & 827 & 68.8 & 32.9 & $<1.8$ & 200.2 \\
Fat (\%) & 531 & 5.6 & 3.2 & 1.0 & 21.7 \\
Protein (\%) & 542 & 12.7 & 3.3 & 2.6 & 20.5 \\
Lactose (\%) & 538 & 2.9 & 0.5 & 1.2 & 4.6 \\
Other solids (\%) & 544 & 4.3 & 0.5 & 1.1 & 8.8 \\
TS (\%) & 496 & 22.6 & 4.7 & 1.7 & 7.3 \\
$\log _{10}$ SCC & 548 & 5.9 & 0.8 & 3.8 & 6.8 \\
Log $_{10}$ TPC $^{1}$ & 548 & 4.9 & 0.9 & 3.0 & \\
\hline
\end{tabular}

${ }^{1} \mathrm{TPC}=$ total plate count.

respective laboratory for analysis of $\mathrm{IgG}$, nutrient composition, and bacterial contamination. Samples were classified based on storage before feeding: fresh = no storage, refrigerated $=$ stored in a refrigerator, or frozen $=$ stored in a freezer. Additional information, including sample origin (individual cow or pooled), breed, and lactation number were recorded for each sample. No attempt was made to determine refrigerator or freezer operating temperature, length of storage or method, of thawing frozen MC.

\section{Radial Immunodiffusion Analysis}

Following arrival at the laboratory (Iowa State University, Ames), MC was thawed in a warm water bath and thoroughly mixed before IgG analysis by radial immunodiffusion (RID). One milliliter of MC was added to $3 \mathrm{~mL}$ of distilled water and mixed well. Five microliters of diluted colostrum solution was pipetted into each well of a bovine IgG RID test plate (Triple J Farms, Bellingham, WA). All MC samples were run in duplicate.

\section{Nutrient and Bacterial Analysis}

The second frozen MC sample was shipped on dry ice to the DHI laboratory (Dubuque, IA) for nutrient and bacterial analysis. Fat, protein, lactose, TS, and other solids were analyzed on a Foss MilkoScan FT+ and SCC was determined using a Foss Fossomatic FC somatic cell counter (Foss A/S, Hillerød, Denmark). Total bacterial plate counts were performed with the Petrifilm Plate Loop Count method as outlined in section 6.030 of the 17th Edition of the Standard Methods for the Examination of Dairy Products (Wehr, 2004). Coliform counts were performed with the Petrifilm Coliform Count Plate Method (SMEDP 7.071).

\section{Statistical Analysis}

The Univariate procedure of SAS (version 9.2; SAS Institute, 2008) was used to determine the frequency of observations and determine if there were any outlier samples to remove from the data set.

Immunoglobulin $\mathrm{G}$ concentration and nutrient and bacterial data from MC samples were analyzed using the PROC GLM procedure of SAS (SAS Institute, 2008) to determine effects of lactation number (1 to $3+$ ), breed (Holstein or Jersey), storage method (fresh, refrigerated, or frozen), and region of the United States (Northeast, Midwest, Southeast, or Southwest). Statistical significance was declared when $P \leq 0.05$.

\section{RESULTS}

\section{Descriptive Analysis}

A total of $827 \mathrm{MC}$ samples were analyzed for this study. Samples were collected from 734 individual cows and $93 \mathrm{MC}$ pools. Samples were obtained from $494 \mathrm{Hol}-$ steins, 87 Jerseys, 7 crossbreds, and 239 unidentified cattle (Table 1). Cows were in their first lactation (n $=49)$, second lactation $(\mathrm{n}=174)$, and third or greater lactation $(\mathrm{n}=128)$. Lactation numbers of 476 animals were not reported.

\section{Composition Data}

Overall sample means for IgG, fat, protein, TS, other solids, SCC, coliform, and TPC are given in Table 2.

Region. Samples from the Midwest had the greatest IgG concentrations $(P<0.05)$ of the 4 regions (Table 3$)$. Fat content of $\mathrm{MC}$ was greatest $(P \leq 0.05)$ in samples from the Midwest. Protein content was greater in the Midwest and Northeast $(P<0.05)$. The concentration of lactose was lowest in the Southeast. Other solids were greater in samples from the Northeast $(P<0.05)$ and similar for samples collected from the Southeast, Southwest, and Midwest. Total solids contents were greater in samples collected from the Northeast and Midwest as compared with the Southeast and Southwest. Samples collected from the Southwest had greater $(P<0.05)$ SCC as compared with the Northeast; no other regional differences were observed for SCC. Co- 
Table 3. Nutrient, bacterial, IgG, and SCC means by region of the country

\begin{tabular}{lccccc}
\hline & \multicolumn{4}{c}{ Region $^{1}$} \\
\cline { 2 - 4 } Item & Northeast & Southeast & Midwest & Southwest & SE \\
\hline IgG $(\mathrm{mg} / \mathrm{mL})$ & $71.5^{\mathrm{b}}$ & $66.9^{\mathrm{ab}}$ & $79.7^{\mathrm{c}}$ & $64.3^{\mathrm{a}}$ & 2.9 \\
Fat (\%) & $5.9^{\mathrm{ab}}$ & $5.2^{\mathrm{a}}$ & $6.4^{\mathrm{b}}$ & $5.2^{\mathrm{a}}$ & 0.3 \\
Protein $(\%)$ & $13.6^{\mathrm{b}}$ & $12.3^{\mathrm{a}}$ & $13.5^{\mathrm{b}}$ & $12.1^{\mathrm{a}}$ & 0.3 \\
Lactose (\%) & $3.0^{\mathrm{c}}$ & $2.7^{\mathrm{a}}$ & $2.9^{\mathrm{bc}}$ & $2.9^{\mathrm{bc}}$ & 0.1 \\
Other solids (\%) & $4.8^{\mathrm{b}}$ & $4.3^{\mathrm{a}}$ & $4.3^{\mathrm{a}}$ & $4.3^{\mathrm{a}}$ & 0.1 \\
TS (\%) & $23.8^{\mathrm{b}}$ & $20.6^{\mathrm{a}}$ & $24.1^{\mathrm{b}}$ & $21.6^{\mathrm{a}}$ & 0.6 \\
$\log _{10}$ SCC & $5.7^{\mathrm{a}}$ & $5.8^{\mathrm{ab}}$ & $5.9^{\mathrm{ab}}$ & $6.0^{\mathrm{b}}$ & 0.1 \\
$\log _{10}$ TPC & $4.9^{\mathrm{a}}$ & $5.7^{\mathrm{b}}$ & $4.9^{\mathrm{a}}$ & $4.8^{\mathrm{a}}$ & 0.1 \\
$\log _{10}$ coliform & $1.3^{\mathrm{b}}$ & $1.1^{\mathrm{a}}$ & $1.0^{\mathrm{ab}}$ & $1.5^{\mathrm{c}}$ & 0.1 \\
\hline
\end{tabular}

${ }^{\mathrm{a}-\mathrm{c}}$ Means within a row with different superscript letters differ $(P<0.05)$.

${ }^{1}$ Region of the United States: Northeast = New Hampshire, New York, and Pennsylvania; Southeast = Florida, Georgia, and Virginia; Midwest = Indiana, Minnesota, and Wisconsin; Southwest = Arizona, California, and Texas.

${ }^{2} \mathrm{TPC}=$ total plate count.

liform counts were greatest in the Southwest, whereas TPC was greatest in samples collected from the Southeast.

Storage. Samples of MC stored in a refrigerator before collection had the highest protein, TS, TPC, and coliform counts compared with fresh and frozen samples $(P<0.05)$. Fresh MC had the lowest protein and TPC $(P<0.05)$ and greatest lactose content. Refrigerated samples had the lowest $\operatorname{SCC}(P<0.05)$. No differences existed between storage methods for fat or IgG (Table 4).

Breed. Colostrum samples collected from Holsteins had greater $(P \leq 0.05)$ SCC, coliform counts, and TPC compared with MC samples collected from Jerseys. No other nutrient differences were observed between breed. The IgG concentration was similar for both breeds (Table 5).

Parity. The concentration of IgG increased $(P \leq$ $0.05)$ with parity and SCC decreased with increasing parity $(P \leq 0.05)$. Fat content was greatest in samples

Table 4. Nutrient, bacterial, IgG, and SCC means by storage method before sample collection

\begin{tabular}{lcccc}
\hline & \multicolumn{3}{c}{ Storage method } \\
\cline { 2 - 4 } Item & Fresh & Refrigerated & Frozen & SE \\
\hline IgG (mg/mL) & 69.0 & 74.6 & 66.3 & 7.3 \\
Fat (\%) & 4.9 & 5.4 & 5.6 & 0.5 \\
Protein (\%) & $10.9^{\mathrm{a}}$ & $14.1^{\mathrm{c}}$ & $12.56^{\mathrm{b}}$ & 0.6 \\
Lactose (\%) & $3.2^{\mathrm{b}}$ & $2.8^{\mathrm{a}}$ & $2.9^{\mathrm{a}}$ & 0.1 \\
Other solids (\%) & $4.6^{\mathrm{b}}$ & $4.3^{\mathrm{a}}$ & $4.4^{\mathrm{a}}$ & 0.1 \\
TS (\%) & $21.2^{\mathrm{a}}$ & $24.2^{\mathrm{b}}$ & $22.3^{\mathrm{a}}$ & 0.9 \\
$\log _{10}$ SCC & $5.8^{\mathrm{b}}$ & $5.5^{\mathrm{a}}$ & $5.6^{\mathrm{b}}$ & 0.1 \\
$\log _{10}$ coliform & $1.1^{\mathrm{a}}$ & $1.6^{\mathrm{b}}$ & $1.3^{\mathrm{a}}$ & 0.1 \\
$\log _{10}$ TPC & $4.0^{\mathrm{a}}$ & $5.0^{\mathrm{c}}$ & $4.5^{\mathrm{b}}$ & 0.1 \\
\hline
\end{tabular}

$\overline{{ }^{\mathrm{a}-\mathrm{c}} \text { Means within a row with different superscript letters } \operatorname{differ}(P<}$ $0.05)$.

${ }^{1} \mathrm{TPC}=$ total plate count. collected from cattle in their first lactation $(P \leq 0.05)$. No differences in protein were observed. Lactose was greater $(P \leq 0.05)$ in samples collected from cattle in their third lactation compared with samples collected from second-lactation cattle; no difference was observed between samples collected from cattle in their first and third or first and second lactation. Other solids and TS were lowest $(P \leq 0.05)$ in samples collected from cattle in their second lactation. Coliform counts were greatest $(P \leq 0.05)$ in samples collected from secondlactation cattle. Total plate count was greater $(P \leq$ 0.05) in samples collected from cattle in their second lactation as compared with third lactation; however, no difference was found between first and second or first and third lactations.

Pooling. Samples collected from individual cows had a greater $(P \leq 0.05) \mathrm{IgG}$, protein, and TS content compared with pooled MC samples (Table 6). Coliform, TPC, and SCC were greater $(P \leq 0.05)$ in pooled samples as compared with individual MC samples. No differences were observed for fat, lactose, or other solids content.

\section{Quality Analysis}

A total of 593 samples (70.6\%) had IgG concentrations greater than the industry-recommended $50 \mathrm{mg} /$ $\mathrm{mL}$, whereas only $409(54.8 \%)$ had a TPC $<100,000$ $\mathrm{cfu} / \mathrm{mL}$ (Table 7 ). Only $39.4 \%$ of samples met both industry recommendations for IgG and TPC. An additional $31.2 \%$ of samples met the IgG recommendation but not the TPC limit, and $15.4 \%$ met the TPC recommendation but not the $\mathrm{IgG}$ recommendation. A total of $14.0 \%$ did not meet either recommendation (Table 8).

Region. Similar percentages of samples met both recommendations for the Northeast, Midwest, and Southwest (45.3, 53.7, and $43.2 \%$, respectively), where- 
Table 5. Nutrient, bacterial, IgG, and SCC means by breed and lactation

\begin{tabular}{|c|c|c|c|c|c|c|c|}
\hline \multirow[b]{2}{*}{ Item } & \multicolumn{3}{|c|}{ Breed } & \multicolumn{3}{|c|}{ Lactation } & \multirow[b]{2}{*}{$\mathrm{SE}$} \\
\hline & Holstein & Jersey & $\mathrm{SE}$ & 1 & 2 & $3+$ & \\
\hline $\mathrm{IgG}(\mathrm{mg} / \mathrm{mL})$ & 74.2 & 65.8 & 8.3 & $42.4^{\mathrm{a}}$ & $68.6^{\mathrm{b}}$ & $95.9^{\mathrm{c}}$ & 9.3 \\
\hline Fat $(\%)$ & 5.3 & 5.3 & 0.5 & $6.6^{\mathrm{c}}$ & $4.2^{\mathrm{a}}$ & $5.1^{\mathrm{b}}$ & 0.5 \\
\hline Protein $(\%)$ & 12.5 & 12.6 & 0.7 & 12.4 & 12.1 & 13.1 & 0.7 \\
\hline Lactose $(\%)$ & 3.0 & 2.9 & 0.1 & $3.0^{\mathrm{ab}}$ & $2.8^{\mathrm{a}}$ & $3.1^{\mathrm{b}}$ & 0.1 \\
\hline Other solids (\%) & 4.4 & 4.4 & 0.1 & $4.4^{\mathrm{b}}$ & $4.2^{\mathrm{a}}$ & $4.6^{\mathrm{b}}$ & 0.1 \\
\hline $\mathrm{TS}(\%)$ & 22.2 & 23.0 & 0.9 & $23.5^{\mathrm{b}}$ & $20.8^{\mathrm{a}}$ & $23.4^{\mathrm{b}}$ & 1.0 \\
\hline $\log _{10} \mathrm{SCC}$ & $5.9^{\mathrm{b}}$ & $5.3^{\mathrm{a}}$ & 0.1 & $6.0^{\mathrm{c}}$ & $5.6^{\mathrm{b}}$ & $5.3^{\mathrm{a}}$ & 0.2 \\
\hline $\log _{10}$ coliform & $1.5^{\mathrm{b}}$ & $1.2^{\mathrm{a}}$ & 0.1 & $1.2^{\mathrm{a}}$ & $1.5^{\mathrm{b}}$ & $1.3^{\mathrm{a}}$ & 0.1 \\
\hline $\log _{10} \mathrm{TPC}^{1}$ & $4.9^{\mathrm{b}}$ & $4.1^{\mathrm{a}}$ & 0.1 & $4.5^{\mathrm{ab}}$ & $4.7^{\mathrm{b}}$ & $4.3^{\mathrm{a}}$ & 0.1 \\
\hline
\end{tabular}

${ }^{\mathrm{a}-\mathrm{C}}$ Means within a row with different superscript letters differ $(P<0.05)$.

${ }^{1} \mathrm{TPC}=$ total plate count.

as only $14.9 \%$ of samples from the Southeast met both recommendations. Numerically, the Southeast had a larger percentage of samples that met the IgG recommendation but not the TPC recommendation (47.4\%) compared with the other regions. The Southeast also had a numerically greater percentage of samples that did not meet either recommendation (Table 8).

Storage. Fresh and frozen samples had similar percentages of samples that had TPC below 100,000 cfu/ $\mathrm{mL}$ ( 67 and $61.2 \%$, respectively), whereas only $23 \%$ of refrigerated samples fell below this value. A total of $38.2 \%$ of refrigerated samples had a TPC over 1 million, but only $12.1 \%$ of fresh and $11.2 \%$ of frozen samples fell above this value (Table 9). Similar percentages of fresh $(42 \%)$ and frozen $(46.7 \%)$ samples met both quality recommendations. Only $18.5 \%$ of refrigerated samples met both industry recommendations. A large percentage of refrigerated samples (53.1\%) met the IgG recommendation but were over the TPC limit (Table 10).

Pooling. Numerically, a greater percentage of individual samples met both recommendations for IgG and TPC as compared with pooled samples (41.2 vs.

Table 6. Nutrient, bacterial, IgG, and SCC means of individual samples compared with pooled maternal colostrum samples

\begin{tabular}{|c|c|c|c|}
\hline \multirow[b]{2}{*}{ Item } & \multicolumn{3}{|c|}{ Pooled } \\
\hline & No $(\mathrm{n}=734)$ & Yes $(\mathrm{n}=93)$ & $\mathrm{SE}$ \\
\hline $\operatorname{IgG}(\mathrm{mg} / \mathrm{mL})$ & $69.7^{\mathrm{b}}$ & $60.3^{\mathrm{a}}$ & 3.6 \\
\hline Fat $(\%)$ & 5.7 & 6.1 & 0.6 \\
\hline Protein (\%) & $13.2^{\mathrm{b}}$ & $10.9^{\mathrm{a}}$ & 0.6 \\
\hline Lactose (\%) & 2.9 & 2.9 & 0.1 \\
\hline Other solids $(\%)$ & $4.4^{\mathrm{b}}$ & $4.6^{\mathrm{a}}$ & 0.1 \\
\hline $\mathrm{TS}(\%)$ & $23.2^{\mathrm{b}}$ & $21.0^{\mathrm{a}}$ & 1.1 \\
\hline $\log _{10}$ SCC & $5.7^{\mathrm{a}}$ & $6.2^{\mathrm{b}}$ & 0.2 \\
\hline $\log _{10} \mathrm{TPC}^{1}$ & $4.9^{\mathrm{a}}$ & $5.5^{\mathrm{b}}$ & 0.1 \\
\hline $\log _{10}$ coliform & $1.3^{\mathrm{a}}$ & $2.0^{\mathrm{b}}$ & 0.1 \\
\hline
\end{tabular}

$25.6 \%$ ). Similar percentages of samples met the $\operatorname{IgG}$ recommendation but were above the TPC recommendation (Table 11). Lactation and breed did not affect the percentage of samples that met one or both industry recommendations (data not presented).

\section{DISCUSSION}

The data presented in this paper represents MC that was available to feed calves during the months of June through October 2010, and is not necessarily representative of the MC produced by all dairy cattle in the United States during all seasons. Colostrum that was discarded after milking and never entered the feeding pool was not sampled. Storage method was determined by where the MC was stored before collection of the sample; it does not indicate the temperature or length of storage time. It is well known that nutrient and $\operatorname{IgG}$ composition of MC changes throughout the first 6 milkings postpartum (Foley and Otterby, 1978) and can be influenced by breed, parity (Muller and Ellinger, 1981; Kume and Tanabe, 1993; Gulliksen et al., 2008), dry

Table 7. Percentage of samples distributed across IgG and total plate count (TPC) concentrations

\begin{tabular}{lcc}
\hline Concentration & No. of samples & \% of samples \\
\hline IgG $(\mathrm{mg} / \mathrm{mL})$ & & \\
$<50$ & 243 & 29.4 \\
I50-80 & 303 & 36.6 \\
$80-100$ & 156 & 18.9 \\
$100-120$ & 75 & 9.1 \\
$>120$ & 50 & 6.00 \\
Total & 827 & 100 \\
TPC (cfu/mL) & & \\
$<100,000$ & 409 & 54.8 \\
$100,000-300,000$ & 90 & 12.1 \\
$300,000-500,000$ & 47 & 6.3 \\
$500,00-1,000,000$ & 74 & 9.9 \\
$>1,000,000$ & 126 & 16.9 \\
Total & 746 & 100 \\
\hline
\end{tabular}


Table 8. Percentage of samples meeting one or both industry recommendations for colostrum quality

\begin{tabular}{|c|c|c|c|c|c|c|c|c|c|c|}
\hline \multirow[b]{3}{*}{ Item $^{1}$} & \multirow{2}{*}{\multicolumn{2}{|c|}{ Overall data set }} & \multicolumn{8}{|c|}{ Region $^{2}$} \\
\hline & & & \multicolumn{2}{|c|}{ Northeast } & \multicolumn{2}{|c|}{ Southeast } & \multicolumn{2}{|c|}{ Midwest } & \multicolumn{2}{|c|}{ Southwest } \\
\hline & $\mathrm{n}$ & $\%$ & $\mathrm{n}$ & $\%$ & $\mathrm{n}$ & $\%$ & $\mathrm{n}$ & $\%$ & $\mathrm{n}$ & $\%$ \\
\hline \multicolumn{11}{|l|}{ Quality } \\
\hline $\begin{array}{l}\mathrm{IgG}>50 \mathrm{mg} / \mathrm{mL} \text { and } \\
\mathrm{TPC}<100,000 \mathrm{cfu} / \mathrm{mL}\end{array}$ & 294 & 39.4 & 58 & 45.3 & 17 & 14.9 & 88 & 53.7 & 177 & 43.2 \\
\hline $\begin{array}{l}\mathrm{IgG}<50 \mathrm{mg} / \mathrm{mL} \text { and } \\
\mathrm{TPC}>100,000 \mathrm{cfu} / \mathrm{mL}\end{array}$ & 104 & 14.0 & 28 & 21.9 & 14 & 12.3 & 14 & 8.5 & 83 & 20.2 \\
\hline $\begin{array}{l}\mathrm{IgG}<50 \mathrm{mg} / \mathrm{mL} \text { and } \\
\mathrm{TPC}<100,000 \mathrm{cfu} / \mathrm{mL}\end{array}$ & 115 & 15.4 & 10 & 7.8 & 29 & 25.4 & 11 & 6.7 & 54 & 13.2 \\
\hline Total & 746 & 100 & 128 & 100 & 114 & 100 & 164 & 100 & 410 & 100 \\
\hline
\end{tabular}

${ }^{1} \mathrm{TPC}=$ total plate count.

${ }^{2}$ Region of the United States: Northeast = New Hampshire, New York, and Pennsylvania; Southeast = Florida, Georgia, and Virginia; Midwest $=$ Indiana, Minnesota, and Wisconsin; Southwest $=$ Arizona, California, and Texas .

period length, time of milking postpartum, and individual farm (Gulliksen et al., 2008). This paper provides additional data on regional and storage differences on $\mathrm{MC}$ quality and nutrient composition.

\section{Colostrum Quality}

The mean IgG concentration of samples collected was greater than that reported by Kehoe et al. (2007; 34.9 $\pm 12.23 \mathrm{mg} / \mathrm{mL}$ ), similar to that reported by Chigerwe et al. $(2008 ; 68.5 \pm 32.4 \mathrm{mg} / \mathrm{mL}$, and lower than that reported by Bielmann et al. (2010; $94.4 \mathrm{mg} / \mathrm{mL})$. Many factors can affect IgG concentration of $\mathrm{MC}$ and may explain the variation in sample means across these studies. Volume of colostrum produced, parity, dry period length, vaccination, and other factors have been reported to affect IgG content (Weaver et al., 2000).

Similar to that in previous research, IgG concentration increased in MC as parity increased (Devery-Pocius and Larson, 1983; Donovan et al., 1986). It has been suggested that the increase in IgG concentration is due to an increase in antigenic exposure and incidence of disease (Jensen and Christensen, 1975; Donovan et al., 1986). Colostrum production is often lower in first- lactation cattle, suggesting less mammary development and potentially reduced transport capacity for IgG into the mammary gland (Devery-Pocius and Larson, 1983).

Current industry recommendations include discarding $\mathrm{MC}$ with less than $50 \mathrm{mg}$ of $\mathrm{IgG} / \mathrm{mL}$. In this study, $29.4 \%$ of MC had IgG concentrations less the recommended IgG level, thus potentially putting almost 30\% of US calves at risk of failure of passive transfer (FPT). The overall percentage of samples containing $<50 \mathrm{mg}$ of $\mathrm{IgG} / \mathrm{mL}$ is lower than the $57.8 \%$ reported in a study that represented MC quality in Norwegian dairy cattle (Gulliksen et al., 2008). The greater percentage of pooled samples containing $<50 \mathrm{mg} / \mathrm{mL} \mathrm{IgG} \mathrm{is} \mathrm{poten-}$ tially due to dilution of IgG by larger volumes of lowquality colostrum. Regionally, the samples collected in the Midwest had the greatest IgG concentration and the greatest percentage of samples containing $>50 \mathrm{mg}$ of $\mathrm{IgG} / \mathrm{mL}$.

A second quality measurement of $\mathrm{MC}$ is bacterial contamination. Johnson et al. (2007) demonstrated that higher bacterial loads decreased uptake of IgG when newborn calves were fed $3.8 \mathrm{~L}$ of pasteurized MC $(813 \mathrm{cfu} / \mathrm{mL})$ or $3.8 \mathrm{~L}$ of raw MC $(40,738 \mathrm{cfu} /$ $\mathrm{mL})$. Calves receiving the $\mathrm{MC}$ with lower bacterial

Table 9. Percentage of samples distributed across total plate count (TPC) by storage method before feeding

\begin{tabular}{|c|c|c|c|c|c|c|}
\hline \multirow[b]{2}{*}{ Item } & \multicolumn{2}{|c|}{ Fresh samples } & \multicolumn{2}{|c|}{ Refrigerated samples } & \multicolumn{2}{|c|}{ Frozen samples } \\
\hline & $\mathrm{n}$ & $\%$ & $\mathrm{n}$ & $\%$ & $\mathrm{n}$ & $\%$ \\
\hline \multicolumn{7}{|l|}{ TPC (cfu/mL) } \\
\hline$<100,000$ & 122 & 67.0 & 35 & 23.0 & 252 & 61.2 \\
\hline $100,000-300,000$ & 21 & 11.5 & 17 & 11.2 & 52 & 12.6 \\
\hline $300,000-500,000$ & 9 & 5.0 & 10 & 6.6 & 28 & 6.8 \\
\hline $500,00-1,000,000$ & 8 & 4.4 & 32 & 21.0 & 34 & 8.2 \\
\hline$>1,000,000$ & 22 & 12.1 & 58 & 38.2 & 46 & 11.2 \\
\hline Total & 182 & 100 & 152 & 100 & 412 & 100 \\
\hline
\end{tabular}


Table 10. Percentage of samples meeting one or both industry recommendations for colostrum quality by storage method before sample collection

\begin{tabular}{|c|c|c|c|c|c|c|}
\hline \multirow[b]{2}{*}{ Item } & \multicolumn{2}{|c|}{ Fresh samples } & \multicolumn{2}{|c|}{ Refrigerated samples } & \multicolumn{2}{|c|}{ Frozen samples } \\
\hline & $\mathrm{n}$ & $\%$ & $\mathrm{n}$ & $\%$ & $\mathrm{n}$ & $\%$ \\
\hline $\mathrm{IgG}>50 \mathrm{mg} / \mathrm{mL}$ and $\mathrm{TPC}<100,000 \mathrm{cfu} / \mathrm{mL}$ & 76 & 42.0 & 30 & 18.5 & 188 & 46.7 \\
\hline $\mathrm{IgG}>50 \mathrm{mg} / \mathrm{mL}$ and $\mathrm{TPC}>100,000 \mathrm{cfu} / \mathrm{mL}$ & 38 & 21.0 & 86 & 53.1 & 109 & 27.0 \\
\hline $\mathrm{IgG}<50 \mathrm{mg} / \mathrm{mL}$ and $\mathrm{TPC}>100,000 \mathrm{cfu} / \mathrm{mL}$ & 21 & 11.6 & 38 & 23.5 & 45 & 11.2 \\
\hline IgG $<50 \mathrm{mg} / \mathrm{mL}$ and $\mathrm{TPC}<100,000 \mathrm{cfu} / \mathrm{mL}$ & 46 & 25.4 & 8 & 4.9 & 61 & 15.1 \\
\hline
\end{tabular}

contamination had greater 24-h serum IgG concentrations compared with their counterparts $(22.3$ and 18.1 $\mathrm{mg} / \mathrm{mL}$, respectively). Although both groups of calves obtained adequate passive transfer, the apparent efficiency of absorption of IgG was decreased in calves fed MC with greater bacterial contamination (33 vs. $27 \%$ ). Our study observed that total coliform counts were well below the current industry recommendation of $<10,000 \mathrm{cfu} / \mathrm{mL}$ (McGuirk and Collins, 2004). Over $50 \%$ of the MC samples collected in our study had TPC less than $100,000 \mathrm{cfu} / \mathrm{mL}$; however, over $27 \%$ of the samples collected had TPC greater than 500,000 cfu/ $\mathrm{mL}$. This introduces a huge immunological challenge to newborn calves who are not equipped to handle a large pathogen load.

Regionally, the Southeast had the greatest mean TPC and greatest percentage of samples containing $>100,000 \mathrm{cfu} / \mathrm{mL}$. This is potentially due to the hot and humid climate that supports bacterial growth. The majority of the samples collected from the Southeast were fresh or refrigerated. Data were collected on these samples as to the length of time that colostrum sat at room temperature before storage and length of storage time. These data will be analyzed for a separate management survey and may provide more details as to why the Southeast had the greatest TPC. Over $60 \%$ of the samples that were fresh or frozen before sample collection had TPC below 100,000 cfu/mL, whereas over $40 \%$ of refrigerated samples had TPC higher than 1 million $\mathrm{cfu} / \mathrm{mL}$. Storage method affects MC quality by altering bacterial growth and shelf life. Previous research has observed that refrigeration slows pathogen growth compared with unrefrigerated samples if $\mathrm{MC}$ is stored for $24 \mathrm{~h}$ (Stewart et al., 2005). It is hoped that data collected for the colostrum management will provide more details as to why refrigerated samples had greater TPC. Data to be analyzed includes length of colostrum storage at room temperature before refrigeration, length of refrigeration, and length of time at room temperature before feeding. Data were not collected on the actual internal temperature of the refrigerator. Had this data been collected, storage temperature may have been a contributing factor. Current recommendations are for $\mathrm{MC}$ to be refrigerated if fed within $24 \mathrm{~h}$ of collection and frozen if it is going to be stored for more than $24 \mathrm{~h}$ (BAMN, 2001). The National Animal Health Monitoring System report (NAHMS, 2007a) observed that $60.7 \%$ of $\mathrm{MC}$ being hand fed was fed fresh or stored without refrigeration, $11.1 \%$ was refrigerated, and $28.2 \%$ was frozen before feeding.

In the United States, $19.2 \%$ of calves have FPT and $7.8 \%$ of heifer calves that are born alive die before weaning (NAHMS, 2007a). Providing adequate MC is one practice that can decrease these values. Although a large percentage of samples contained either adequate IgG $(70.6 \%)$ or a TPC below the recommended limit $(54.8 \%)$, less than $40 \%$ of samples met both recommendations.

Our laboratory is continuing to analyze survey data that were collected on each MC sample with the goal of identifying key management practices that affect colostral quality. Although accurate on-farm methods

Table 11. Percentage of samples meeting one or both industry recommendations for colostrum quality by pooling

\begin{tabular}{|c|c|c|c|c|}
\hline \multirow[b]{2}{*}{ Item } & \multicolumn{2}{|c|}{ Not pooled samples } & \multicolumn{2}{|c|}{ Pooled samples } \\
\hline & $\mathrm{n}$ & $\%$ & $\mathrm{n}$ & $\%$ \\
\hline \multicolumn{5}{|l|}{ Quality } \\
\hline $\mathrm{IgG}>50 \mathrm{mg} / \mathrm{mL}$ and $\mathrm{TPC}<100,000 \mathrm{cfu} / \mathrm{mL}$ & 272 & 41.2 & 22 & 25.6 \\
\hline IgG $>50 \mathrm{mg} / \mathrm{mL}$ and $\mathrm{TPC}>100,000 \mathrm{cfu} / \mathrm{mL}$ & 201 & 30.5 & 32 & 37.2 \\
\hline $\mathrm{IgG}<50 \mathrm{mg} / \mathrm{mL}$ and $\mathrm{TPC}>100,000 \mathrm{cfu} / \mathrm{mL}$ & 81 & 12.3 & 23 & 26.7 \\
\hline IgG $<50 \mathrm{mg} / \mathrm{mL}$ and $\mathrm{TPC}<100,000 \mathrm{cfu} / \mathrm{mL}$ & 106 & 16.0 & 9 & 10.5 \\
\hline Total & 660 & 100 & 86 & 100 \\
\hline
\end{tabular}


of evaluating IgG content in colostrum are available, unfortunately at this time, no rapid and accurate test exists that producers can use on-farm to evaluate bacterial contamination in MC.

\section{Nutrient Composition}

The mean fat content of the entire sample set was slightly lower (5.6 vs. 6.7\%) as compared with that cited by both Kehoe et al. (2007) and Foley and Otterby (1978) and greater than that reported by Fleenor and Stott (1980), Quigley et al. (1994), and Tsioulpas et al. (2007). Similar to the Quigley et al. (1994) data set, fat content in MC was highly variable in this study (1.02 to 21.69\%). Low fat content in MC affects calf viability, as newborn calves are born with limited fat (380 to $600 \mathrm{~g})$ and glycogen $(180 \mathrm{~g})$ reserves (Okamota et al., 1986), and calves less than $10 \mathrm{~d}$ of age exhibit high rates of metabolism (Roy et al., 1957).

Lactose is the primary carbohydrate in MC and milk, providing $3.95 \mathrm{kcal} / \mathrm{g}$ (Brisson et al., 1957). During the first 3 milkings postpartum, the lactose content increases $(2.7,3.9$, and $4.4 \%$, respectively; Foley and Otterby, 1978). Recently, reports confirm that lactose continues to increase until $30 \mathrm{~d}$ postpartum (Tsioulpas et al., 2007). Lactose was the least variable component in this data set. The low lactose concentrations in samples from the Southeast and in refrigerated samples may be related to the high TPC in these samples, as bacteria may be using lactose as an energy substrate.

Protein is the third component of MC that can be an energy source, although it is more important as an AA source. The high rate of tissue protein turnover in young calves may be responsible for the low efficiency of use of ME for protein gain (Geay, 1984). Colostrum contains more total protein than milk (14.0 vs. $3.2 \%$ ) and a greater percentage of IgG (6.0 vs. $0.09 \%$; Foley and Otterby, 1978). Total protein in MC and milk decreases rapidly from $1 \mathrm{~d}$ postpartum $(16.12 \pm 1.82)$ to $2 \mathrm{~d}$ postpartum $(5.43 \pm 0.24)$ and continues to decrease until $30 \mathrm{~d}$ postpartum $(3.08 \pm 0.19$; Tsioulpas et al., 2007). Nonimmunoglobulin protein potentially provides $5.60 \mathrm{kcal} / \mathrm{g}$ (Brisson et al., 1957) as well as providing essential AA needed for protein accretion. Using neonatal lambs as a model, $35 \%$ of the dietary AA ingested in $\mathrm{MC}$ was available within $4 \mathrm{~h}$ for AA metabolism (Yvon et al., 1993). It was previously reported that protein content was lowest in first-lactation cattle, and increased in second- and third-lactation Holstein cattle $(15.1,16.9$, and $18.8 \%$, respectively; Kume and Tanabe, 1993). The mean protein content of the sample set was lower (22.6 vs. $27.6 \%$ ) than previously reported by Kehoe et al. (2007). We did not observe any parity or breed differences in protein content that may have explained this difference, but did observe differences in protein content by the storage method. Foley and Otterby (1978) previously reported that storage of MC at ambient temperatures leads to a decrease in $\mathrm{pH}$, TS, protein, fat, and lactose, whereas freezing resulted in virtually no nutrient loss. Protein concentration was greater in refrigerated and frozen samples compared with fresh samples.

\section{SCC}

New mastitis infections often occur during the dry period, and can affect MC quality. Gulliksen et al. (2008) reported that an SCC of greater than 50,000 cells $/ \mathrm{mL}(\log \mathrm{SCC}=4.7)$ was the only test-day result found to be significant for the production of $\mathrm{MC}$ with very low $\operatorname{IgG}$ values (less than $30 \mathrm{mg} / \mathrm{mL}$ ). Kehoe et al. (2007) reported that farms with a herd average SCC $<200,000$ the month before colostrum was collected had greater $\operatorname{IgG}_{2}$ as compared with farms with an SCC $>200,000$ ( 7.27 vs. $5.15 \mathrm{mg} / \mathrm{mL}$ ). Our study observed a weak relationship between $\log$ SCC and IgG but did observe that all MC samples with $\operatorname{IgG}$ concentrations less than $25 \mathrm{mg} / \mathrm{mL}$ had $\log$ SCC greater than 5.6. The NAHMS (2007b) dairy study reported no regional differences in bulk tank SCC when the country was divided as East and West. The MC samples from the Northeast had lower log SCC compared with the Southwest; however, no other regional differences were observed. It is well documented that cow cleanliness is related to SCC (Schreiner and Ruegg, 2003; Sant'Anna and Paranhos da Costa, 2011). Maintaining clean and dry transition cow facilities is one management practice that can help reduce not only SCC, but also TPC and coliform count of MC before parturition. Cow cleanliness was not recorded as a part of this study; however, housing, bedding source, dry treatment protocols, and udder preparation methods were recorded to be analyzed in the management study.

\section{CONCLUSIONS}

The objectives of this study were to characterize the IgG concentration, bacterial contamination, and nutrient composition of $\mathrm{MC}$ available on US dairy operations. Storage method of MC has a significant effect on bacterial contamination. Based on this data set, MC should be fed fresh or frozen immediately and not stored in a refrigerator. This study observed IgG concentration in MC ranging from $<1.8$ to $200.2 \mathrm{mg} /$ $\mathrm{mL}$; of the 827 samples collected, $29.4 \%$ did not meet the industry standard (greater than $50 \mathrm{mg}$ of $\mathrm{IgG} / \mathrm{mL}$ ). Bacterial contamination of MC continues to be a problem on many farms, with only $54.8 \%$ of the samples 
having a TPC less than the industry recommendation of $100,000 \mathrm{cfu} / \mathrm{mL}$, with the greatest problems occurring in the Southeast region of the United States. When both industry standards for MC quality were combined, only $39.41 \%$ percent of samples were adequate; this value was $53.7 \%$ in the Midwest and only $14.9 \%$ in the Southeast. Data collected from this study indicates that a large percentage of calves are being put at risk for both FPT and pathogen exposure when fed MC currently available on US farms.

\section{REFERENCES}

BAMN (Bovine Alliance on Management and Nutrition). 2001. A guide to colostrum and colostrum management for dairy calves. American Feed Industry Association (AFIA), Arlington, VA.

Bielmann, V., J. Gillan, N. R. Perkins, A. L. Skidmore, S. Godden, and K. E. Leslie. 2010. An evaluation of Brix refractometry instruments for measurement of colostrum quality in dairy cattle. J. Dairy Sci. 93:3713-3721.

Bösze, Z., M. Baranyi, and C. B. Whitelaw. 2008. Producing recombinant human milk proteins in the milk of livestock species. Adv. Exp. Med. Biol. 606:357-393.

Brisson, G. J., H. M. Cunningham, and S. R. Haskell. 1957. The protein and energy requirements of young dairy calves. Can. J. Anim. Sci. 37:152-156.

Chigerwe, M., J. W. Tyler, J. R. Middleton, J. N. Spain, J. S. Dill, and B. J. Steevens. 2008. Comparison of four methods to assess colostral IgG concentration in dairy cows. J. Am. Vet. Med. Assoc. 233:761-766.

Davis, C. L., and J. K. Drackley. 1998. The Development, Nutrition and Management of the Young Calf. Iowa State Press, Ames, IA.

Devery-Pocius, J. E., and B. L. Larson. 1983. Age and previous lactations as factors in the amount of bovine colostral immunoglobulins. J. Dairy Sci. 66:221-226.

Donovan, G. A., L. Badinga, R. J. Collier, C. J. Wilcox, and R. K. Braun. 1986. Factors influencing passive transfer in dairy calves. J. Dairy Sci. 69:754-759.

Fleenor, W. A., and G. H. Stott. 1980. Hydrometer test for estimation of immunoglobulin concentration in bovine colostrum. J. Dairy Sci. 63:973-977.

Foley, J. A., and D. E. Otterby. 1978. Availability, storage, treatment, composition and feeding value of surplus colostrum: A review. J. Dairy Sci. 61:1033-1060.

Fulwider, W. K., T. Grandin, B. E. Rollin, T. E. Engle, N. L. Dalsted, and W. D. Lamm. 2008. Survey of dairy management practices on one hundred thirteen North Central and Northeastern United States dairies. J. Dairy Sci. 91:1686-1692.

Geay, Y. 1984. Energy and protein utilization in growing cattle. J. Anim. Sci. 58:766-778.

Godden, S. 2008. Colostrum management for dairy calves. Vet. Clin. North Am. Food Anim. Pract. 24:19-39.

Gulliksen, S. M., K. I. Lie, L. Sølverød, and O. Østerås. 2008. Risk factors associated with colostrum quality in Norwegian dairy cows. J. Dairy Sci. 91:704-712.

James, R. E., and C. E. Polan. 1978. Effect of orally administered duodenal fluid on serum proteins in calves. J. Dairy Sci. 61:14441449.

James, R. E., C. E. Polan, and K. A. Cummins. 1981. Influence of administered indigenous microorganisms on uptake of [iodine-125] $\gamma$-globulin in vivo by intestinal segments of neonatal calves. J. Dairy Sci. 64:52-61.

Jensen, P. T., and K. Christensen. 1975. Genetic analysis of the serum level of $\mathrm{IgG}_{2}$ and total protein in Red Danish cattle. J. Anim. Sci. 40:392-396.

Johnson, J. L., S. M. Godden, T. Molitor, T. Ames, and D. Hagman. 2007. Effects of feeding heat-treated colostrum on passive transfer of immune and nutritional parameters in neonatal dairy calves. J. Dairy Sci. 90:5189-5198.

Kehoe, S. I., B. M. Jayarao, and A. J. Heinrichs. 2007. A survey of bovine colostrum composition and colostrum management practices on Pennsylvania dairy farms. J. Dairy Sci. 90:4108-4116.

Kume, S., and A. Tanabe. 1993. Effect of parity on colostral mineral concentrations of Holstein cows and value of colostrum as a mineral source for newborn calves. J. Dairy Sci. 76:1654-1660.

McGuirk, S. M., and M. Collins. 2004. Managing the production, storage and delivery of colostrum. Vet. Clin. North Am. Food Anim. Pract. 20:593-603.

Muller, L. D., and D. K. Ellinger. 1981. Colostral immunoglobulin concentrations among breeds of dairy cattle. J. Dairy Sci. 64:17271730.

NAHMS (National Animal Health Monitoring System). 2007a. Dairy 2007: Heifer calf health and management practices on U.S. dairy operations, 2007. United States Department of Agriculture:Animal and Plant Health Inspection Service:Veterinary Services:Centers for Epidemiology and Animal Health (USDA:APHIS:VS:CEAH), Fort Collins, CO.

NAHMS (National Animal Health Monitoring System). 2007b. Dairy 2007: Part III: Reference of dairy cattle health and management practices in the United States, 2007. United States Department of Agriculture: Animal and Plant Health Inspection Service: Veterinary Services: Centers for Epidemiology and Animal Health (USDA:APHIS:VS:CEAH), Fort Collins, CO.

Nocek, J. E., D. G. Braund, and R. G. Warner. 1984. Influence of neonatal colostrum administration, immunoglobulin, and continued feeding of colostrum on calf gain, health and serum proteins. J. Dairy Sci. 67:319-333.

NRC. 2001. Nutrient Requirements of Dairy Cattle. 7th rev. ed. Natl. Acad. Sci., Washington, DC.

Okamota, M., J. B. Robinson, R. J. Christopherson, and B. A. Young. 1986. Summit metabolism of newborn calves with and without colostrum feeding. Can. J. Anim. Sci. 66:937-944.

Quigley, J. D., K. R. Martin, H. H. Dowlen, L. B. Wallis, and K. Lamar. 1994. Immunoglobulin concentration, specific gravity, and nitrogen factions of colostrum from Jersey cattle. J. Dairy Sci. $77: 264-269$.

Roy, J. H. B., C. F. Huffman, and E. P. Reineke. 1957. The basal metabolism of the newborn calf. Br. J. Nutr. 11:373-381.

Sant'Anna, A. C., and M. J. R. Paranhos da Costa. 2011. The relationship between dairy cow hygiene and somatic cell count in milk. J. Dairy Sci. 94:3835-3844.

SAS Institute. 2008. SAS User's Guide. Version 9.2. SAS Institute Inc., Cary, NC.

Schreiner, D. A., and P. L. Ruegg. 2003. Relationship between udder and leg hygiene scores and subclinical mastitis. J. Dairy Sci. 86:3460-3465.

Stewart, S., S. Godden, R. Bey, P. Rapnicki, J. Fetrow, R. Farnsworth, M. Scanlon, Y. Arnold, L. Clow, K. Mueller, and C. Ferrouillet. 2005. Preventing bacterial contamination and proliferation during harvest, storage, and feeding of fresh bovine colostrum. J. Dairy Sci. 88:2571-2578.

Talukder, M. J. R., T. Takeuchi, and E. Harada. 2002. Transport of colostral macromolecules into the cerebrospinal fluid via plasma in newborn calves. J. Dairy Sci. 85:514-524.

Tsioulpas, A., A. D. Grandison, and M. J. Lewis. 2007. Changes in physical properties of bovine milk from the colostrum period to early lactation. J. Dairy Sci. 90:5012-5017.

Weaver, D. M., J. W. Tyler, D. C. VanMetre, D. E. Hostetler, and G. M. Barrington. 2000. Passive transfer of colostral immunoglobulins in calves. J. Vet. Intern. Med. 14:569-577.

Wehr, H. M., and J. F. Frank, ed. 2004. Standard Methods for the Examination of Dairy Products. 17th ed. Am. Public Health Assoc. Inc., Washington, DC.

Yvon, M., D. Levieux, M.-C. Valluy, J.-P. Pélissier, and P. P. Mirand. 1993. Colostrum protein digestion in newborn lambs. J. Nutr. 123:586-596. 